\title{
Importance of animal/human health interface in potential Public Health Emergencies of International Concern in the Americas
}

\author{
Maria Cristina Schneider, ${ }^{1}$ Ximena P. Aguilera, ${ }^{1}$ Ryan M. Smith, ${ }^{1}$ \\ Matthew J. Moynihan, ${ }^{1}$ Jarbas Barbosa da Silva Jr., ${ }^{1}$ \\ Sylvain Aldighieri, ${ }^{1}$ and Maria Almiron ${ }^{1}$
}

Suggested citation Schneider MC, Aguilera XP, Smith RM, Moynihan MJ, Barbosa da Silva J Jr, Aldighieri S, et al. Importance of animal/human health interface in potential Public Health Emergencies of International Concern in the Americas. Rev Panam Salud Publica. 2011;29(5):371-9.

\begin{abstract}
This study analyzed the importance of zoonoses and communicable diseases common to man and animals as potential Public Health Emergencies of International Concern to build an evidence base for future efforts to reduce risk of infection at the animal/human health interface. The events recorded in the World Health Organization (WHO) Event Management System (EMS) database for the Americas during the 18 months since the implementation of the 2005 revised version of WHO's International Health Regulations (15 June 2007-31 December 2008) were the main source for this analysis. Of the 110 events recorded by the EMS for the Americas during the study period, 86 were classified as communicable diseases-77 (70.0\%) "within the animal/human health interface," $9(8.2 \%)$ "not common to man and animals," 16 (14.5\%) "syndromes with unknown etiologies," and 8 (7.3\%) "product-related/other." Of the 77 events within the animal/human health interface, 48 were "substantiated" (the presence of hazard was confirmed and/or human cases occurred clearly in excess of normal expectancy). These results confirm previous research and underscore the importance of the animal/human health interface as well as inter-sectoral collaboration.
\end{abstract}

Key words Communicable diseases; epidemiology; veterinary public health; zoonoses; Americas.

In today's globalized world, diseases have the potential to transcend geopolitical boundaries through international travel and trade. It is now understood that the economies and livelihoods of the entire international community can be affected by a single health crisis in one

\footnotetext{
Health Surveillance and Disease Prevention and Control, Pan American Health Organization, Washington, D.C., United States of America. Send correspondence to: Cristina Schneider, schneidc@paho.org
}

country. With this concept in mind, a revised version of the World Health Organization (WHO) International Health Regulations (IHRs) was established in 2005 (effective 15 June 2007) to "help the international community prevent and respond to acute public health risks that have the potential to cross borders and threaten people worldwide" (1). This binding legal instrument covers 194 countries across the globe, including all WHO Member States, and aims to protect public health through the prevention of the spread of diseases.
For that purpose and as part of IHR implementation, WHO Member States are committed to strengthening their surveillance of and ability to rapidly detect, assess, notify, and report potential Public Health Emergencies of International Concern (PHEICs) in accordance with these regulations. A PHEIC is an extraordinary event that has been determined, as provided in the IHRs, to 1) "constitute a public health risk to other States through the international spread of disease" and 2) "potentially require a coordinated international response" (1). 
Events are identified as potential PHEICs and reported to the six WHO IHR (2005) Regional Contact Points when they fulfill at least two of the following four criteria: 1) a serious public health event is suspected, 2) the event is considered unusual or unexpected, 3 ) there is a significant risk of international spread, and 4) the event poses a significant risk to international travel or trade (2). For the Americas region, the Pan American Health Organization (PAHO) has been mandated to undertake certain activities to support countries in the detection and assessment of these potential public health emergencies.

Events that have been reported or detected as potential PHEICs are entered into a database known as the Event Management System (EMS), which is administered by WHO and used by the six WHO IHR (2005) Regional Contact Points as well as the WHO Country Offices in each region. The EMS is the central electronic repository for information related to potential PHEICs and provides chronological storage of clinical, epidemiological, laboratory, and other types of data used in risk assessment and major operational decision-making for managing the event (3).

To date, $61 \%$ of human pathogens worldwide have been classified as zoonoses, a subgroup that comprises $75 \%$ of all emerging pathogens of the past decade (4). There is a growing beliefechoed in the "One World, One Health" strategic framework endorsed by the Food and Agriculture Organization (FAO), the World Organization for Animal Health (OIE), WHO, the United Nations Children's Fund (UNICEF), the United Nations System Influenza Coordination (UNSIC), and the World Bank-that an integrated approach to public health events is most effective and efficient with collaboration between physicians, veterinarians, and other health-related disciplines (5).

The myriad demographic and socioeconomic conditions that exist in the countries of the Americas imply broad challenges related to the animal/human health interface. The region is home to close to 1 billion people ( $80 \%$ in urban areas) distributed across 48 countries and territories, with national populations ranging from 40000 (in St. Kitts \& Nevis) to 300 million (in the United States), and purchasing power parity-based gross na- tional income ranging from approximately US\$ 1000 to US\$ 44000 per capita per year (6). In addition, the Americas contain a wide range of environmental settings characterized by diverse plants and animals. For example, the Amazon region comprises $60 \%$ of the Earth's remaining tropical forests, with 45000 plant species, 1300 species of freshwater fish, 1000 species of birds, 150 species of bats, 1800 species of butterflies, 163 species of amphibians, 305 species of snakes, and 311 species of mammals (7). This flora and fauna interacts synergistically with the human population to create a unique and rich environment that is very im_portant to the planet. On the other hand, this rich synergy can pose a potential threat by forming an environment in which pathogens/diseases can emerge and spread across the animal/ human interface, affecting tourism, trade, and other economic sectors important to the region.

A more in-depth analysis of the events recorded by the EMS and a study of their likeliness to be ultimately verified as PHEICs could be valuable for policy development as well as technical orientation of institutional activities related to surveillance, prevention, and rapid response. The primary objective of this analysis is to identify, quantify the importance of, and analyze diseases common to animals and humans in events recorded by the EMS for the Americas region in an effort to produce an evidence base for future recommendations on how to address and reduce the risk of infectious diseases at the animal/human health interface.

\section{MATERIALS AND METHODS}

\section{Data sources}

This study is based on data for the Americas region recorded by the $\mathrm{WHO}$ EMS from June 15, 2007, until December 31, 2008, ${ }^{2}$ and includes potential PHEICs ("events") tracked by PAHO/WHO. The data used in the study were obtained directly from the EMS database, which comprises information from various sources including the IHR National Focal

\footnotetext{
2 Because the study period occurred prior to the $\mathrm{A}(\mathrm{H} 1 \mathrm{~N} 1)$ influenza pandemic, the research was not affected by the subsequent system-wide shift toward coverage of that disease.
}

Point, [non-IHR] national government agencies, and the PAHO surveillance system. The initial source of information on a particular event may be unofficial as well as official. Unofficial sources include the mass media (both traditional and Internet-based). The PAHO surveillance system includes reports provided by laboratories and WHO technical units and programs. Information gathered through unofficial sources are verified and evaluated jointly by $\mathrm{PAHO} / \mathrm{WHO}$ experts and the country where the event occurred. Official information comes in the form of notifications by the IHR National Focal Point (the entity designated by each WHO Member State to serve as its liaison with WHO on IHR-related matters).

\section{Criteria}

Within the context of the IHRs, an "event" is a manifestation of disease or an occurrence that creates a potential for disease (1). In this study, events were classified within the animal/human health interface based on information from the third edition of the PAHO publication "Zoonoses and communicable diseases common to man and animals" (8), which describes 174 communicable infections ranging from diseases of bacterial, viral, and parasitic origin to those involving unconventional agents. Although this publication did not cover all communicable diseases, the authors of the current study did not consider the resulting data gaps to be a significant research limitation as the current study was designed to improve technical cooperation rather than for academic purposes. Any disease not found in the above-cited publication was cross-checked in other communicable disease publications to confirm that it was not common to animals (9).

All events recorded in the EMS are assigned a category related to a potential hazard ("animal," "chemical," "disaster," "food safety," "infectious," "product," or "undetermined"). These same categories were applied in the current study as long as they were deemed sufficient for discerning the animal/human health interface. When they were not, for the purposes of this study, new categories related to the hazard(s) described in the EMS were created. Based on their assigned categories, events were classified into four groups, one of which (Group 1) was further divided into four 
FIGURE 1. Number and proportion of events ${ }^{\mathrm{a}}$ recorded for the Americas region in the WHO Event Management System, by group/subgroup, ${ }^{\text {b }} 15$ June 2007-31 December 2008

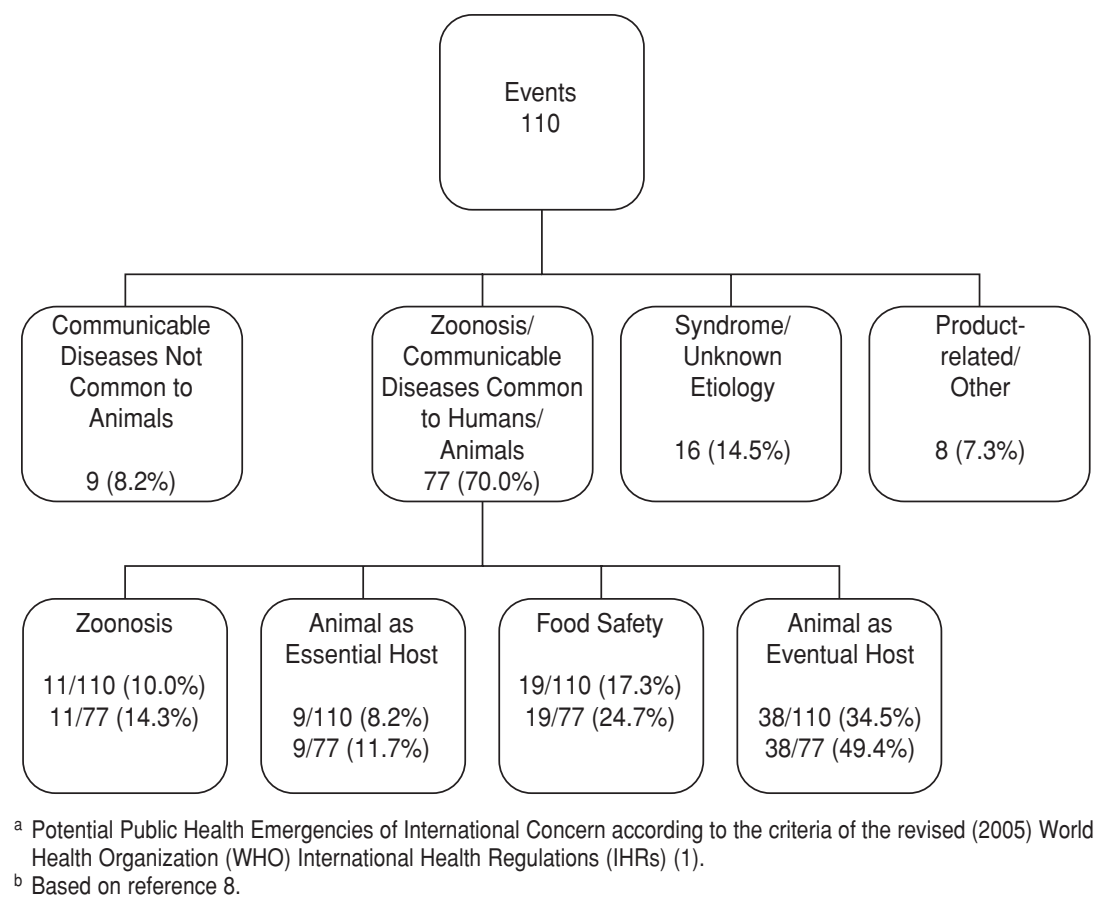

subgroups based on the dynamic of disease transmission ${ }^{3}$ :

- Group 1: Zoonoses and communicable diseases common to humans and animals

- Subgroup 1a-Zoonosis, a communicable disease or infection whose agent is directly transmitted from vertebrate animals to humans

- Subgroup $1 \mathrm{~b}$-Communicable disease common to humans and animals in which vector transmission occurs and animals are essential hosts in the life cycle of the pathogen

- Subgroup 1c-Communicable disease common to humans and animals related to food safety, with transmission through the food chain and water supply

- Subgroup 1d-Communicable disease common to humans and animals in which animals are eventual

\footnotetext{
3 While most diseases had more than one type of transmission dynamic, for the purposes of this study subgroup classification was based on the one most common in the Americas.
}

hosts in the life cycle of the pathogen

- Group 2: Communicable diseases not common to animals (i.e., diseases in which there is no direct transmission between animals and humans and animals do not act as "reservoirs" and are not involved in the life cycle of the pathogen)

- Group 3: Syndromes with no known etiology (diseases that are not clearly defined and for which symptoms may be present but no etiology has been identified)

- Group 4: Product-related and "other" (public health concerns that are not considered communicable diseases and are attributed to a product, chemical, or other material).

\section{Analysis}

Event data recorded in the EMS for the Americas region were exported to Microsoft Excel, version 2003 (Redmond, WA, USA). Events occurring during the 18month study period were examined and event variables pertinent to this analysis were selected. The selected events and relevant variables were compiled in a sub- database and classified by group and subgroup according to the abovementioned criteria. Group/subgroup percentages were calculated and events classified within the animal/human health interface (Group 1) were analyzed. The analysis included determining which events were designated as "substantiated" (presence of hazard confirmed and/or human cases occurring clearly in excess of normal expectancy) upon completion of the original event investigation.

\section{RESULTS}

A total of 110 events were recorded in the EMS for the Americas region during the 18-month study period (Figure 1). Of those, 86 were communicable diseases, including $77(70.0 \%)$ classified as "common to man and animals" (Group 1) (e.g., influenza, yellow fever, salmonella infections, and dengue), and $9(8.2 \%)$ that were "not common to man and animals" (Group 2) (e.g., hemorrhagic chickenpox, rubella, and meningococcal disease). Of the remaining 24 events recorded by the EMS, which were deemed noncommunicable, 16 (14.5\%) were "syndromes with unknown etiologies" (Group 3) (e.g., 
acute hemorrhagic fever syndrome, acute respiratory syndrome, and acute neurological syndrome), and $8(7.3 \%)$ were "product-related or other" (Group 4) (e.g., adverse vaccine effects or chemical gas/toxic solvent exposure).

The 77 events classified in Group 1 (i.e., within the animal/human health interface) were further divided as follows: Subgroup 1a, "zoonosis" (11 events, representing $14.3 \%$ of the group total, with influenza the most frequent); Subgroup $1 b$, "animals as essential hosts" (9 events, or $11.7 \%$, with yellow fever the most frequent); Subgroup 1c, "food safety" (19 events, or $24.7 \%$, with salmonella infections the most frequent); and Subgroup 1d, "animals as eventual hosts" (38 events, or $49.4 \%$, with dengue the most frequent) (Table 1). Events that were recorded at least twice within a particular subgroup included influenza (representing 7.8\% of the subgroup total) and rabies (2.6\%) (Subgroup 1a); yellow fever (7.8\%) and leptospirosis (3.9\%) (Subgroup 1b); salmonella $(7.8 \%)$, listeriosis $(3.9 \%)$, botu- lism (2.6\%), and Chagas disease (oral transmission) (2.6\%) (Subgroup 1c); and measles $(20.8 \%)$, dengue $(18.2 \%)$, and tuberculosis (5.2\%) (Subgroup 1d).

Among the 77 events classified in Group 1, 48 (62.3\%) were deemed "substantiated" upon completion of the original event investigation. Subgroup 1a ("zoonosis") had the highest percentage of substantiated events $(81.8 \%)$ while Subgroup 1d ("animals as eventual host") had the lowest (50.0\%) (Figure 2).

The most recommended interventions for Group 1 events were distributed as follows: vector control (32.5\% of events), food safety $(31.2 \%)$, direct intervention in animals (14.3\%), and "other" (22.1\%). In addition to comprising about onethird of suggested interventions, the "food safety" classification applied to $17.3 \%$ of all events analyzed in the study.

Subgroup 1d ("animal as eventual host") comprised the smallest percentage of substantiated events $(47.4 \%$, with a large proportion primarily related to dengue). In other words, although events in this subgroup were considered important in the Americas and were monitored accordingly, the ultimate number of human cases in more than $50 \%$ of "events" did not exceed normal expectancy when the events were verified. As mentioned above, Subgroup 1a ("zoonosis") comprised the highest percentage of substantiated events $(81.8 \%)$, suggesting that events in this subgroup have a higher probability of being classified as substantiated than those in other subgroups.

\section{DISCUSSION}

This analysis indicated that approximately $70 \%$ of events reported to the EMS by WHO Member States or detected by the PAHO surveillance system were either zoonoses or communicable diseases common to man and animals, supporting previous research results indicating that $75 \%$ of all emerging diseases in humans are zoonotic $(10,11)$. This information suggests that carrying

TABLE 1. Type and number of events ${ }^{a}$ recorded for the Americas region in the WHO EMS ${ }^{b}$ and classified within the animal/human health interface, ${ }^{c} 15$ June 2007-31 December 2008

\begin{tabular}{|c|c|c|c|}
\hline Type of event (pathogen/disease) & $\begin{array}{l}\text { Classification } \\
\text { subgroupd }^{d}\end{array}$ & No. of events & $\begin{array}{c}\text { No. of } \\
\text { substantiated events }\end{array}$ \\
\hline Angiostrongyliasis (nematode) & $1 d$ & 1 & 1 \\
\hline Botulism & $1 c$ & 2 & 1 \\
\hline Bubonic plague & $1 b$ & 1 & 0 \\
\hline Campylobacter enteritis & $1 c$ & 1 & 1 \\
\hline Chagas (American trypanosomiasis) & $1 c$ & 2 & 2 \\
\hline Cholera & $1 c$ & 1 & 1 \\
\hline Dengue & $1 d$ & 14 & 3 \\
\hline Escherichia coli infection & $1 c$ & 1 & 0 \\
\hline Hepatitis A (acute) & $1 d$ & 1 & 0 \\
\hline Influenza & $1 a$ & 6 & 4 \\
\hline Leptospirosis & $1 \mathrm{a}$ & 3 & 3 \\
\hline Listeriosis & $1 c$ & 3 & 3 \\
\hline Malaria & $1 d$ & 2 & 2 \\
\hline Measles & $1 d$ & 16 & 12 \\
\hline Rabies & $1 a$ & 2 & 2 \\
\hline Rickettsiosis (tick-borne) & $1 b$ & 1 & 0 \\
\hline Salmonella infection & $1 c$ & 6 & 6 \\
\hline Streptococcus Group A & $1 c$ & 1 & 0 \\
\hline Tuberculosis & $1 d$ & 4 & 1 \\
\hline Variant Creutzfeldt-Jakob disease & $1 c$ & 1 & 0 \\
\hline Venezuelan equine encephalitis & $1 b$ & 1 & 0 \\
\hline Yellow fever & $1 b$ & 6 & 6 \\
\hline $\begin{array}{l}\text { Mixed etiology: Cryptosporidium, giardiasis, } \\
\text { shigella }\end{array}$ & $1 c$ & 1 & 0 \\
\hline Total & & 77 & 48 \\
\hline
\end{tabular}

a Potential Public Health Emergencies of International Concern according to the criteria of the revised (2005) World Health Organization (WHO) International Health Regulations (IHRs) (1).

b Event Management System.

c Based on reference 8.

d Subgroup 1a: "zoonosis"; Subgroup 1b, "animal as essential host"; Subgroup 1c, "food safety"; Subgroup 1d, "animal as eventual host."

e Presence of hazard confirmed and/or human cases occurring clearly in excess of normal expectancy. 
FIGURE 2. Number and proportion of events ${ }^{\mathrm{a}}$ in the Americas region (unsubstantiated and substantiated ${ }^{b}$ ) recorded in the World Health Organization Event Management System and classified within the animal/human health interface, ${ }^{c}$ by subgroup, ${ }^{d} 15$ June 2007-31 December 2008

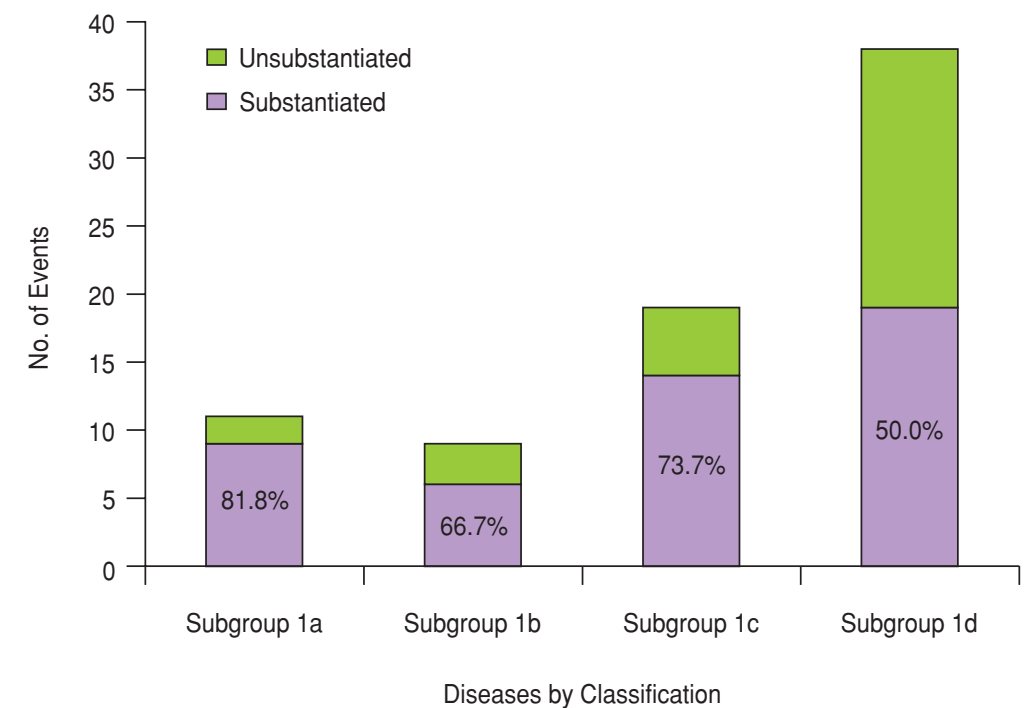

a Potential Public Health Emergencies of International Concern according to the criteria of the revised (2005) World Health Organization (WHO) International Health Regulations (IHRs) (1).

b Presence of hazard confirmed and/or human cases occurring clearly in excess of normal expectancy.

c Based on reference 8.

d Subgroup 1a, "zoonosis"; Subgroup 1b, "animal as essential host"; Subgroup 1c, "food safety"; Subgroup 1d, "animal as eventual host."

out proper detection, risk assessment, and verification will require collaboration among the health sciences (veterinary and human) as well as other sectors. It also underscores the need for a better understanding of infectious diseases common to man and animals. Analyzing which diseases represent a higher risk at the animal/human health interface in the Americas region is an essential step.

Most of the diseases recorded in the EMS for the Americas region during the period of this study had a known occurrence in the region. However, the emergence of new strains is always a possibility, as has occurred with the Ebola virus, human immunodeficiency virus (HIV), severe acute respiratory syndrome (SARS), influenza A (H5N1) with a pandemic potential, West Nile virus, and the Novel A(H1N1) influenza virus (12-15).

Estimating when diseases could surpass the expected number of human cases or spread to areas where they were not previously found requires baseline information on the current status and trends of the disease. Countries need to have strong surveillance systems in place or other sources of information that allow for evidence-based decision-making.
The results presented above illustrate to some extent the need to pursue efforts already in place in the Americas. The pathogens/diseases listed in Table 1 under Subgroups 1a and 1b (20 events distributed across seven diseases, including influenza, leptospirosis, rabies, plague, rickettsiosis, Venezuelan equine encephalitis, and yellow fever) are to various extents the focus of current surveillance and control activities developed by the health and/or agricultural institutions in the region. For example, the avian influenza pandemic that began at the end of 2005 in Asia led to the development of global, inter-sectoral strategic plans and activities in the Americas (16-18). Rabies prevention has also been a successful program in the region, leading to a $90 \%$ reduction of human and canine cases in the last few decades $(19,20)$. Human rabies (transmitted by dogs) and plague are both part of a recent resolution project with the goal of elimination in the Americas (21). Many countries in the region are already developing surveillance and control strategies for leptospirosis (22-24). Rickettsiosis and Venezuelan equine encephalitis were the subjects of several studies in the Americas, following the initial expert consultation in the region (25). The reemergence of yellow fever, on the other hand, may be considered a new trend for the region (26).

Most importantly, the success of several disease programs in many countries or areas cannot undermine the fact that if some areas are left behind in the control efforts, it may threaten others that have already achieved an elimination status. An example of this type of situation can be seen in the reintroduction of rabies in Cordoba, Argentina, after more than six years without canine cases (27), and in the reintroduction of rabies from bats in Costa Rica after 31 years (28). This type of occurrence points to the importance of maintaining surveillance activities and the resources needed to control an emergent/re-emergent disease situation, even when the epidemiological situation has improved.

The study results also underscore the importance of food safety events as potential PHEICs in the region. A recent example is the introduction of bovine tuberculosis in New York City, which may be a result of the rapid shipment of homemade cheeses from foreign countries (29). Another example is that of acute Chagas disease, which is caused by the oral trans- 
mission of Trypanosoma cruzi, possibly through the contamination of food by the vector's feces. Outbreaks of Chagas diseases as a food-borne illness have been reported more frequently in Latin America in recent years, mostly in Brazil (30-34). Food safety is an area to which international organizations and countries of the region have been devoting significant attention, not only to improve public health but also to protect tourism and trade. Tourism is very important to the Americas' economies, with US\$171 billion in regional revenue attributed to international travel (35), and represents $14.8 \%$ of the Caribbean subregion's gross domestic product (GDP) (36).

In the case of some diseases common to animals, the investigation alone can have an important impact on trade related to animal products. This effect may be seen across several countries in the cases of avian influenza and Novel $\mathrm{A}(\mathrm{H} 1 \mathrm{N1})$ influenza virus (37). The economic loss from a disease related to trade was analyzed by Bio Economic Research Associates (Cambridge, MA, USA), which concluded that billions of dollars were lost, based on several examples worldwide (38). As the Americas region accounts for one-third of global meat production (39), better collaborative efforts among sectors and multidisciplinary teams for the purpose of the IHRs and other epidemic alert and response events are crucial to maintaining economic stability. This emphasizes the importance of international organizations supporting the countries with further guidelines and proper training in addition to existing programs $(40,41)$.

For most of the diseases listed in Subgroups $1 \mathrm{a}$ and $1 \mathrm{~b}$, there are cases of disease transmission patterns congruent with interactions between humans, animals, and the environment. For example, outbreaks of human rabies transmitted by vampire bats in remote areas of the Amazon region could be related to changes in local productive processes such as gold mining, deforestation, and interruption of cattle raising (42). Also, several leptospirosis outbreaks have occurred in areas following flood disasters, when contact between animals (such as rats), people, and the environment becomes elevated $(43,44)$. In addition, domiciliary outbreaks of plague have been detected in the Andean region in South America, where people occasionally share living space with cuye (a type of guinea pig raised and consumed to increase protein intake) and where crops attract wild rodents (20). In the case of yellow fever, human cases are related to outbreaks in wild monkeys. Monitoring areas where the virus is known to circulate among animals in the wild would therefore seem worthwhile (45). For all these diseases, inter-sectoral interaction among health, agricultural, and environmental institutions, at all levels, is crucial.

In the case of Subgroup 1d (communicable diseases where animals do not act as a reservoir for infection but eventually become involved in the life cycle of the pathogen), dengue and measles are of interest given their proportional weight in comparison to other events recorded in the EMS. Although these diseases only affect humans, they are included in the reference book on zoonoses used in this study and are relevant to thorough analysis of the animal/human health interface, which seeks to develop approaches to improve understanding of possible crossspecies pathogen transmission. On the same note, the definition of zoonoses in a strict sense is too narrow to define all problems that may derive from animals to human beings (46). Zoonotic pathogens have caused more than $65 \%$ of emerging infectious disease events since 1950, and because the diseases often are new, societies are unprepared to treat them (47). Early detection is essential to the control of emerging, reemerging, and novel infectious diseases, whether naturally occurring or intentionally introduced. Containing the spread of such diseases in a profoundly interconnected world requires active vigilance for signs of an outbreak, rapid recognition of its presence, and diagnosis of its microbial cause, in addition to strategies and resources for an appropriate and efficient response. Although these actions are often viewed in terms of human public health, they also challenge the plant and animal health communities (48).

The different types of dengue virus (DENV) are maintained in two transmission cycles: a sylvatic one between nonhuman primates and sylvatic Aedes mosquitoes, and an endemic cycle between humans and peri-domestic Aedes (49-52). The genetic relationships and phenotypic differences between endemic and sylvatic DENV genotypes may provide valuable insight into the DENV emergence and guide monitoring of future outbreaks and possible interven- tions (51-53). A study developed in French Guyana suggested wild mammals in edge habitats can be infected by circulating human strains (54). Also, because dengue outbreaks can occur in tandem with other vector-borne diseases, such as leptospirosis, investigation and correct diagnosis of the event are important for controlling potential outbreaks. Proper control of the vector for dengue (usually the Aedes aegypti mosquito, in the Americas) requires multidisciplinary teams, including environmental and risk communication professionals, and intersectoral interaction (55). Dengue is the most important arboviral pathogen in tropical and subtropical regions throughout the world and is therefore a critical issue in the Americas $(51,52)$. WHO considers dengue a "tool-deficient" disease, meaning further research is needed to develop better interventions (56).

For measles, the transmission usually occurs person-to-person and the intervention activities, such as vaccination, are therefore directly related to humans (9), making the importance of veterinary medicine or animal biology in the investigation less relevant. Also, in the case of measles events, it is important to consider the potential risk of an anthropozoonotic (human to nonhuman animal) transmission of the disease, which poses a threat to wildlife, in this case nonhuman primates. Outbreaks and serological evidence of nonhuman primate infections have already been reported in relation to tourism and employees of a monkey house facility (57-59).

Integration or collaboration among sectors that deal with zoonotic diseases is a complex issue involving multiple entities and thus requires the implementation of integration policies, joint training, expanded access to data, and other efforts (60).

A model has been established to identify "hotspots" for emerging infectious diseases, most of them zoonoses (60.3\%), through the analysis of variables related to demographics and the environment (12). The data from the EMS may be used by the countries to support institutions in predicting public health risks and may thus improve efforts toward disease prevention or mitigation.

Risk communication informing the population of a possible threat is very important because in many cases the event will not be covered by the mass media until it materializes as an actual emer- 
gency. Events identified as potential PHEICs thus require a comprehensive response by the public health sector, including lab diagnostics and expanded access to the health system. In today's society, even a rumor of a possible health threat can hamper trade or travel and create significant economic loss. A good example is the response to the Novel A (H1N1) influenza virus pandemic, which has put governments and international organizations under recent scrutiny with regard to their ability to manage PHEICs.

The results of this analysis also call attention to the current education system for health-related sciences and the need to integrate the animal/human health interface into the curriculum. Training professionals with a holistic vision of potential risk situations and the practical aptitude to coordinate actions with different sectors is vital. The veterinary medical discipline is one of the sciences that should consider reviewing their curriculum and accepting more responsibility related to protection of human health (61).

In conclusion, it is clear that better understanding of the occurrence of zoo- noses and diseases common to man and animals in potential PHEICs will allow for more efficient allocation of resources, both financial and human, and better incountry verification and response, supported by international organizations. Multidisciplinary teams including physicians, veterinarians, environmentalists, epidemiologists, communicators, and others are crucial to the success of the IHR implementation.

Evidence-based analysis of the animal/ human health interface could also support new directions in research, vaccines, and treatments, as well as the development of diagnostic tests and other tools, to help prevent, control, eliminate, or mitigate emergent infectious diseases. As mentioned above, and supported by the results of this study, the recommendations of the "One World, One Health" strategic framework-particularly the need to develop surveillance capacity, strengthen public and animal health capacity, strengthen national emergency response, and promote inter-agency and cross-sectoral collaboration-provide some helpful guidance for these types of endeavors (5).
Although the current research was not an analysis of the social determinants of emerging infectious disease events, many of the EMS "zoonosis" events studied are related to poverty in the Americas, as mentioned above with regard to cases of rabies, plague, and leptospirosis $(17,19)$. A comprehensive approach to the problem, incorporating inter-sectoral partners for joint projects (such as improving housing conditions in areas with rabies transmitted by bats, or improving waste management in areas with leptospirosis), is one way to avoid future emergent events.

Solidarity and transparency among the countries in the Americas region is of upmost importance not only for humanitarian reasons but also because one area affected by disease could rapidly threaten others.

Acknowledgments. The authors thank all of the IHR National Focal Points in the Americas that provided the World Health Organization Event Management System with the information that was used in this analysis.

\section{REFERENCES}

1. World Health Organization. International Health Regulations (2005). 2nd ed. Geneva: WHO; 2008

2. Pan American Health Organization. International Health Regulations. In: Pan American Health Organization/World Health Organization 144th Session of the Executive Committee, 60th Session of the Regional Committee. Washington: PAHO; 2009.

3. Pan American Health Organization, Technical Area of Health Surveillance and Disease Prevention and Control. Assessment of potential Public Health Emergencies of International Concern (PHEIC) under the new International Health Regulations (2005). Epidemiol Bull. 2008;27(1).

4. World Health Organization. Zoonoses and veterinary public health. The control of neglected zoonotic diseases [Internet]. Geneva: WHO; 2009. Available from: http://www. who.int/zoonoses/control_neglected_zoo noses/ en/index.html. Accessed 28 July 2009.

5. Food and Agriculture Organization; World Organisation for Animal Health; World Health Organization; United Nations System Influenza Coordinator; United Nations Children's Fund; World Bank. Contributing to One World, One Health: a strategic framework for reducing risks of infectious diseases at the animal-human-ecosystems interface. Rome: FAO; 2008.
6. Pan American Health Organization. Health situation in the Americas: basic indicators 2008 [brochure]. Washington: PAHO; 2008.

7. Encyclopedia Britannica. Interview: Rosalía Arteaga of the Amazon Cooperation Treaty Organization. In: Encyclopedia Britannica's Advocacy for Animals. Available from: http:// advocacy.britannica.com/blog/advocacy/ 2007/04/interview-rosalia-arteaga-of-theamazon-cooperation-treaty- organization/. Accessed 4 August 2009.

8. Acha P, Szyfres B. Zoonoses and communicable diseases common to man and animals. 3rd ed. Washington: Pan American Health Organization; 2003. (Scientific and Technical Pub $580 ; 3 \mathrm{vol})$

9. Heymann DL. Control of communicable diseases manual. 18th ed. Washington: American Public Health Association; 2004.

10. Taylor LH, Latham SM, Woolhouse ME. Risk factors for human disease emergence. Philos Trans R Soc Lond B Biol Sci. 2001;356(1411): 983-9.

11. Chomel BB, Belotto A, Meslin FX. Wildlife, exotic pets, and emerging zoonoses. Emerg Infect Dis. 2007;13(1):6-11.

12. Jones KE, Patel NG, Levy MA, Storeygard A, Balk D, Gittleman JL, et al. Global trends in emerging infectious diseases. Nature. 2008; 451(7181):990-3.
13. Webster RG, Peiris M, Chen H, Guan Y. H5N1 outbreaks and enzootic influenza. Emerg Infect Dis. 2006;12(1):3-8.

14. Centers for Disease Control and Prevention (US). Epidemic/epizootic West Nile Virus in the United States: guidelines for surveillance, prevention, and control. 3rd rev. Fort Collins, CO: CDC; 2003. Available from: http:/ / www. cdc.gov/ncidod/dvbid/westnile/resources/ wnv-guidelines-aug-2003.pdf. Accessed $5 \mathrm{Au}-$ gust 2009.

15. Fraser C, Donnelly CA, Cauchemez S, Hanage WP, Van Kerkhove MD, Hollingsworth TD, et al. WHO Rapid Pandemic Assessment Collaboration: pandemic potential of a strain of influenza A (H1N1): early findings. Science. 2009;324(5934):1557-61.

16. World Health Organization. Global alert and response (GAR). Avian influenza [Internet]. Geneva: WHO; 2009. Available from: http:// www.who.int/csr/disease/avian_influenza/ en/. Accessed 3 August 2009.

17. Food and Agriculture Organization. Global Programme for the Prevention and Control of H5N1 Highly Pathogenic Avian Influenza. Rome: FAO; 2008. Available from: ftp:// ftp.fao.org/docrep/zfao/010/ai380e/ai380e0 0.pdf. Accessed 3 August 2009.

18. Pan American Health Organization. Avian influenza and influenza pandemic preparedness. In: Pan American Health Organiza- 
tion/World Health Organization 48th Directing Council, 60th Session of the Regional Committee. Washington: PAHO; 2008. Available from: http:/ /www.paho.org/English/ GOV/ CD/cd48-inf3-e.pdf. Accessed 3 August 2009.

19. Schneider MC, Belotto A, Adé MP, Hendrickx $\mathrm{S}$, Leanes LF, Rodrigues MJ, et al. Current status of human rabies transmitted by dogs in Latin America. Cad Saude Publica. 2007; 23(9): 2049-63.

20. Belotto A, Leanes LF, Schneider MC, Tamayo $\mathrm{H}$, Correa E. Overview of rabies in the Americas. Virus Res. 2005;111(1): 5-12.

21. Pan American Health Organization. Elimination of neglected diseases and other povertyrelated infections. In: Pan American Health Organization/World Health Organization 144th Session of the Executive Committee, 60th Session of the Regional Committee. Washington: PAHO; 2009.

22. Ministério da Saúde (BR). Vol. II: Guia de vigilância epidemiológica. Brasilia: MS; 2002.

23. Secretaría de Salud (MX). Inundaciones en los estados de Tabasco y Chiapas. Las acciones en salud [PowerPoint presentation]. Available from: portal.salud.gob. $\mathrm{mx} /$ descargas/ppt/ acciones_en_salud.ppt. Accessed 19 September 2010 .

24. World Health Organization. Human leptospirosis: guidance for diagnosis, surveillance, and control. Geneva: WHO; 2003. Available from: http://www.who.int/csr/ don/en/WHO_CDS_CSR_EPH_2002.23.pdf. Accessed 5 August 2009.

25. Pan American Health Organization, Pan American Foot-and-Mouth Disease Center. $\mathrm{PAHO} / \mathrm{WHO}$ experts consultation on Rickettsiosis in the Americas. Final report. Ouro Preto, MG (Brazil): PANAFTOSA; 2004.

26. Pan American Health Organization. Update: yellow fever situation in the Americas. Epidemiological Alerts [newsletter]. Washington: PAHO; 2009. Available from: http:// www.paho.org/ English/AD/DPC/CD/eideer-2009-02-10.pdf. Accessed 3 August 2009.

27. International Society for Infectious Diseases. A case of rabies was detected and massive vaccination was implemented. In: ProMEDmail 18 Apr 2008. Archive 20080418.1395. Available from: http://www.lmcordoba. com.ar/2008/04/17/ nota164492.html. Accessed 5 August 2009.

28. Badilla X, Pérez-Herra V, Quirós L, Morice A, Jiménez E, Sáenz E, et al. Human rabies: a reemerging disease in Costa Rica? Emerg Infect Dis. 2003;9(6): 721-3.

29. Tauxe RV. The burden of illness associated with foodborne threats to health, and the challenge of prevention. In: Addressing foodborne threats to health: policies, practices, and global coordination. Workshop summary. Washington: Institute of Medicine; 2006.

30. Beltrão Hde B, Cerroni Mde P, Freitas DR, Pinto AY, Valente Vda C, Valente SA, et al. Investigation of two outbreaks of suspected oral transmission of acute Chagas Disease in the Amazon region, Para State, Brazil, in 2007. Trop Doct. 2009;39(4):231-2.

31. Benchimol-Barbosa PR. Trends on acute Chagas' disease transmitted by oral route in Brazil: steady increase in new cases and a con- cealed residual fluctuation. Int J Cardiol. 2010;145(3):494-6.

32. Pereira KS, Schmidt FL, Guaraldo AM, Franco RM, Dias VL, Passos LA. Chagas' disease as a foodborne illness. J Food Prot. 2009;72(2): 441-6.

33. Nobrega AA, Garcia MH, Tatto E, Obara MT, Costa E, Sobel J, et al. Oral transmission of Chagas disease by consumption of açaí palm fruit, Brazil. Emerg Infect Dis. 2009;15(4): 653-5.

34. Alarcón de Noya B, Días-Bello Z, Colmenares C, Ruiz-Guevara R, Mauriello L, Zavala-Jaspe $\mathrm{R}$, et al. Large urban outbreak of orally acquired acute Chagas disease at a school in Caracas, Venezuela. J Infect Dis. 2010;201(9): 1308-15.

35. Pan American Health Organization. Health and tourism. In: Pan American Health Organization/World Health Organization 144th Session of the Executive Committee, 60th Session of the Regional Committee. Washington: PAHO; 2009.

36. Pan American Health Organization. Proposed $\mathrm{PAHO} / \mathrm{WHO}$ plan of action for technical cooperation in food safety, 2006-2007. In: FAO/WHO Regional Conference on Food Safety for the Americas and the Caribbean. Final report. Rome: FAO; 2006.

37. Burns A, van der Mensbrugghe D, Timmer $\mathrm{H}$. Evaluating the economic consequences of avian influenza. Washington: World Bank; 2008. Available from: http://siteresources. worldbank.org/EXTAVIANFLU/Resources/ EvaluatingAHIeconomics_2008.pdf. Accessed 5 August 2009.

38. Newcomb J. Economic impact of selected infectious diseases. Cambridge, MA: Bio Economic Research Associates; 2008. Available from: http://www. lulu.com/items/volume_64/4384000/4384064/1/print/can_disease.pdf. Accessed 5 August 2009.

39. Food and Agriculture Organization. FAOSTAT [Internet]. Available from: faostat. fao. org. Accessed 5 August 2009.

40. Food and Agriculture Organization; World Health Organization. Assuring food safety and quality: guidelines for strengthening national food control systems. Rome: FAO; 2003. Available from: http://www.who.int/foodsafety/publications/capacity/en/English_ Guidelines_Food_control.pdf. Accessed $3 \mathrm{Au}-$ gust 2009

41. International Food Safety Authorities Network. The influenza outbreak in humans caused by Influenza A/H1N1: considerations at the human-animal interface. Geneva: World Health Organization; 2009. Available from: http://www.who.int/foodsafety/fs management/No_02_influenza_Apr09_en rev1.pdf. Accessed 5 August 2009.

42. Schneider MC, Aron J, Santos-Burgoa C, Uieda W, Ruiz-Velazco S. Common vampire bat attacks on humans in a village of the Amazon region of Brazil. Cad Saude Publica. 2001;17(6):1531-6.

43. Ahern M, Kovats RS, Wilkinson P, Few R, Matthies F. Global health impacts of floods: epidemiologic evidence. Epidemiol Rev. 2005; 27(1):36-46.

44. Vanasco NB, Schmeling MF, Lotters berger J, Costa F, Ko AI, Tarabla HD. Clinical character- istics and risk factors of human leptospirosis in Argentina (1999-2005). Acta Trop. 2008;107(3): 255-8.

45. Ministério da Saúde (BR). Mortes de macacos e a prevenção da febre amarela no Brasil, 2007 e 2008. Brasilia, DF: MS; 2008. Available from: http://portal. saude.gov.zbr/portal/arquivos/pdf/nota_tecnica_epizootias_macacos jan_2008_v2.pdf. Accessed 3 August 2009.

46. Montovani A. Collaboration between physicians and veterinarians. In: Lasagna $\mathrm{E}$, editor. Collaboration between physicians and veterinarians. Rome: WHO/FAO Collaborating Centre for Research and Training in Veterinary Public Health; [date unknown].

47. Institute of Medicine (US). Sustaining global surveillance and response to emerging zoonotic diseases. Washington: IOM; 2009. Available from: http://iom.edu/Reports/2009/ Zoonotic Disease.aspx. Accessed 27 December 2010.

48. Institute of Medicine (US). Global infectious disease surveillance and detection: assessing the challenges. Workshop summary. Washington: IOM; 2007. Available from: http:// www.iom.edu/Reports/2007/Global-Infectious-Disease-Surveillance-and-DetectionAssessing-the-Challenges-Workshop-Summary.aspx. Accessed 27 December 2010.

49. Pepin KM, Hanley KA. Density-dependent competitive suppression of sylvatic dengue virus by endemic dengue virus in cultured mosquito cells. Vector Borne Zoonotic Dis. 2008;8(6):821-8.

50. Vasilakis N, Fokam EB, Hanson CT, Weinberg E, Sall AA, Whitehead SS, et al. Genetic and phenotypic characterization of sylvatic dengue virus type 2 strains. Virology. 2008; 377(2): 296-307.

51. Vasilakis N, Weaver SC. The history and evolution of human dengue emergence. Adv Virus Res. 2008;72:1-76.

52. Vasilakis N, Shell EJ, Fokam EB, Mason PW, Hanley KA, Estes DM, et al. Potential of ancestral sylvatic dengue-2 viruses to re-emerge. Virology. 2007; 358(2):402-12.

53. Weaver SC. Host range, amplification and arboviral disease emergence. Arch Virol Suppl. 2005;(19):33-44.

54. de Thoisy B, Lacoste V, Germain A, MuñozJordán J, Colon C, Mauffrey JF, et al. Dengue infection in neotropical forest mammals. Vector Borne Zoonotic Dis. 2009;9(2):157-70.

55. Pan American Health Organization. Disasters and Humanitarian Assistance. Technical guidelines. Vector control in disaster situations [Internet]. Available from: http:/ / www. paho.org/english/dd/Ped/te_vect.htm. Accessed 5 August 2009

56. World Health Organization. WHO Global Plan to Combat Neglected Tropical Diseases 2008-2015. Geneva: WHO; 2007. (WHO/ CDS/NTD/2007.3)

57. Willy NE, Woodward PA, Thornton VB, Wolff AV, Flynn BM, Heath JL, et al. Management of a measles outbreak among Old World nonhuman primates. Lab Anim Sci. 1999; 49(1):42-8.

58. Muehlenbein MP, Martinez LA, Lemke AA Ambu L, Nathan S, Alsisto S, et al. Perceived vaccination status in ecotourists and risks of anthropozoonoses. Ecohealth. 2008;5(3):371-8. 
59. Jones-Engel L, Engel GA, Schillaci MA, Lee B, Heidrich J, Chalise $\mathrm{M}$, et al. Considering human-primate transmission of measles virus through the prism of risk analysis. Am J Primatol. 2006;68(9): 868-79.

60. Schneider C, Roca A, Falconi C, Belotto A, Medici A. Avian and human pandemic in- fluenza: addressing the need for integration between health and agriculture in the preparedness plans in Latin America. Washington: Pan American Health Organization/Inter American Development Bank; 2007.

61. Becker KM. An epiphany: recent events highlight the responsibilities, roles, and challenges that veterinarians must embrace in public health. J Vet Med Educ. 2003;30(2):115-20.

Manuscript received on 24 March 2010. Revised version accepted for publication on 30 December 2010.

RESUMEN En este estudio se analizó la importancia de las zoonosis y las enfermedades transmisibles comunes a los seres humanos y los animales como posibles emergencias de salud pública de importancia internacional, a fin de sentar una base científica para las actividades futuras destina-

Importancia de la interfaz entre la salud humana y la sanidad animal en las posibles emergencias de salud pública de importancia internacional en la Región de las Américas

Palabras clave das a reducir el riesgo de infección en la interfaz entre animales y seres humanos. La fuente principal para este análisis fueron los eventos registrados en la base de datos del Sistema de Gestión de Eventos de la Organización Mundial de la Salud (OMS) para las Américas durante los 18 meses que transcurrieron (15 de junio del 2007 al 31 de diciembre del 2008) desde la puesta en marcha del Reglamento Sanitario Internacional de la OMS (versión revisada en el 2005). De los 110 eventos registrados por el Sistema de Gestión de Eventos para las Américas durante el período de estudio, 86 se clasificaron como enfermedades transmisibles - 77 (70,0\%) como "dentro de la interfaz entre animales y seres humanos" y $9(8,2 \%)$ como "no comunes a seres humanos y animales"-, $16(14,5 \%)$ como "sindromes de etiología desconocida", y $8(7,3 \%)$ como "relacionados con productos/otros". De los 77 eventos comprendidos dentro de la interfaz entre animales y seres humanos, se fundamentaron 48 (se confirmó la presencia del riesgo u ocurrieron casos en seres humanos que claramente superaron los casos esperados). Estos resultados confirman las investigaciones anteriores y destacan la importancia de la interfaz entre la salud humana y la sanidad animal, así como la importancia de la colaboración intersectorial.

Enfermedades transmisibles; epidemiología; salud pública veterinaria; zoonosis; Américas. 